\title{
Pentingnya Intervensi / Perencanaan dan juga Implementasi dalam Asuhan Keperawatan
}

\author{
Dea Kristin Sania Manik \\ Deakristin01@gmail.com
}

\section{LATAR BELAKANG}

Keperawatan merupakan suatu bentuk pelayanan profesional bersifat humanistik, menggunakan pendekatan holistik, dilakukan berdasarkan ilmu dan kiat keperawatan, berorientasi kepada kebutuhan objektif klien. Praktek keperawatan mengacu pada standar professional keperawatan dan menggunakan etika keperawatan sebagai tuntutan utama. Perawat dituntut untuk selalu melaksanakan asuhan keperawatan yang benar atau rasional (Nursalam, 2007). Proses asuhan keperawatan merupakan tugas dan kewajiban seorang perawat dari pasien datang sampai pasien pulang, dimulai dengan pengkajian secara menyeluruh, kemudian menegakkan diagnosa keperawatan dari data pengkajian tersebut, serta melaksanakan intervensi, implementasi dan evaluasi keefektifan diagnosa awal yang sudah ditegakkan (Nursalam, 2007). Perilaku adalah semua kegiatan atau aktivitas manusia, baik yang dapat diamati langsung, maupun yang tidak diamati secara langsung, oleh pihak luar. Green (1980) mengemukaan bahwa perilaku dipengaruhi oleh tiga faktor yakni: faktor predisposing (pengetahuan, sikap tradisi, kepercayaan, sistem nilai yang dianut), faktor pemungkin (sarana dan prasarana), faktor penguat (sikap perilaku tokoh masyarakat, petugas, undang-undang,aturan) (Notoatmodjo, 2012). Pelaksanaan asuhan keperawatan profesional diwujudkan dengan menerapkan model praktek keperawatan profesional (MPKP) disetiap ruangan. Menurut Ratna Sitorus (2006 dikutip Nursalam 2007), MPKP adalah suatu sistem (struktur, proses dan nilai-nilai profesional), yang memfasilitasi perawat profesional, mengatur pemberian asuhan keperawatan termasuk lingkungan tempat asuhan keperawatan tersebut. 
Kewenangan Perawat Pasal 15 KEPMENKES No. 1239/MENKES/SK/XI/2001 tentang registrasi dan praktik perawat : a) Melaksanakan asuhan keperawatan yang meliputi pengkajian, penetapan diagnosis keperawatan, perencanaan, melaksanakan tindakan keperawatan dan evaluasi keperawatan; b) Tindakan keperawatan meliputi : intervensi keperawatan , observasi keperawatan, pendidikan dan konseling kesehatan; c) Dalam melaksanakan asuhan keperawatan sebagai dimaksud harus sesuai dengan standar asuhan keperawatan yang ditetapkan oleh organisasi profesi.

Kata Kunci : Asuhan Keperawatan, Intervensi/Perencanaan, Implementasi

\section{METODE}

Penulisan ini dilakukan dengan metode kajian bebas terhadap pokok bahasan yang di kumpulkan dari beberapa sumber yang berkaitan dengan pokok bahasan, seperti jurnal online maupun jurnal print, dan buku online.

Setelah membaca beberapa jurnal dan menyeleksinya penulis menentukan 10 jurnal yang dipilih.

Alasan jurnal yang di pilih diantaranya :

a. Sumbernya jelas

b. Sesuai dengan topik yang diinginkan

c. Batas tahun diterbitkannya artikel tidak lebih dari 10 tahun

\section{HASIL PENELITIAN}

Intervensi dan Implementasi Keperawatan menitikberatkan pada bagaimana proses perencanaan intervensi yang berisi aktivitas yang akan dilakukan perawat kepada pasien serta pencatatan tindakan yang telah dilakukan kepada pasien dan respon pasien terhadap tindakan yang diberikan. Diagnosis yang telah ditegakkan perlu dibuat target luaran guna menyelesaikan masalah keperawatan dengan mengatasi penyebab atau tanda gejalanya, sehingga tujuan yang dibuat harus berdasarkan diagnosis. Tujuan yang telah dibuat tersebut kemudian dianalisis untuk pembuatan rencana intervensi yang diperlukan untuk mencapai tujuan. Sistematika analisis pada 
proses tersebut menunjukkan pentingnya dan krusialnya diagnosis yang ditegakkan oleh perawat atau sebagai produk/hasil analisis perawat terhadap proses kajian berdasarkan tanda gejala yang dirasakan atau muncul pada pasien. Peran kritis diagnosis akan berdampak pada penetapan tujuan dan perencanaan intervensi yang berorientasi pada penyelesaian masalah keperawatan.

Dokumen yang dianalisis dalam penelitian ini menunjukkan bahwa intervensi yang telah direncanakan sudah mencakup aspek tindakan observasi, mandiri, dan kolaborasi. Namun, belum semua berorientasi pada tujuan dan kriteria hasil. Selain itu, spesifikasi intervensi mengenai bagaimana, seberapa sering, dan siapa yang melakukan tindakan belum didukung oleh sistem informasi yang digunakan karena perawat tidak dapat menginput spesifikasi tersebut dalam bentuk isian. Aplikasi dari contoh intervensi yang telah dipaparkan merupakan gambaran penegakkan rencana keperawatan yang akan diimplementasikan pada asuhan keperawatan pasien. Sebagian besar dokumentasi implementasi yang terdapat dalam dokumen penelitian ini, tidak hanya intervensi yang telah direncanakan tetapi juga banyak di luar intervensi yang dicatat seperti proses serah terima pasien antar shift. Catatan respon pasien terhadap tindakan perawat juga belum berorientasi pada kriteria hasil sehingga sulit untuk menilai apakah implementasi dari intervensi yang direncanakan sudah mencapai tujuan atau belum. Selain itu, waktu (tanggal dan jam) pemberian tindakan atau implementasi sudah tercatat dengan baik. Sehingga secara keseluruhan dokumentasi intervensi dan implementasi keperawatan memiliki kategorik sedang sebanyak 66 dokumen (63\%) .

Implementasi asuhan keperawatan spiritual di rumah sakit, seharusnya dilakukan secara utuh, yaitu mengikuti alur proses keperawatan mulai pengkajian spiritual, penentuan diagnosis keperawatan spiritual, membuat perencanaan, implementasi dan evaluasi (Inggriane, 2017), namun kenyataannya pelaksanaan proses keperawatan dalam asuhan spiritual ini masih belum dilaksanakan secara utuh. Penerapan intervensi keperawatan dipengaruhi oleh berbagai faktor, baik faktor internal mau-pun eksternal. Penelitian yang dilakukan oleh Tombokan (2013) menunjukkan bahwa terdapat pengaruh yang signifikan antara pengetahu-an perawat, tingkat pendidikan perawat, serta tingkat keterampilan perawat dengan penerap-an asuhan keperawatan keluarga. 


\section{PEMBAHASAN}

Kualitas asuhan yang berfokus pada tampilan kinerja keperawatan melalui proses keperawatan merupakan sebuah indikator yang penting dan dapat diukur dari dokumentasi keperawatan (Xiao et al., 2017). Sejarah fokus dokumentasi keperawatan sebelumnya berorientasi pada dokumentasi proses keperawatan yang komprehensif dan kemudian berkembang menjadi diagnosis keperawatan yang lengkap namun belum memerhatikan kualitas dari dokumentasi diagnosis keperawatan, intervensi, dan luaran. Hubungan yang logis, berdasarkan teori, dan koheren antara diagnosis, luaran pasien, dan intervensi keperawatan menjadi penekanan yang penting, bahkan diagnosis keperawatan menjadi tidak berfungsi tanpa adanya kaitan dengan luaran dan intervensi. Luaran keperawatan menjadi “jembatan” untuk menstandarisasi hubungan antara diagnosis dengan intervensi. Sedangkan, intervensi keperawatan dinilai untuk mengevaluasi efek intervensi terhadap diagnosis. Diagnosis keperawatan berfungsi untuk meningkatkan kualitas pengkajian yang dilakukan dan didokumentasikan oleh perawat. Diagnosis keperawatan sebagai proses terkait pada kajian deskripsi masalah pasien, penyebabnya, dan dapat memberikan informasi kepada perawat untuk mengidentifikasi pendekatan kajian apa yang sesuai untuk membuat perencanaan spesifik terkait diagnosis keperawatan pasien. Sehingga, secara tidak langsung akan membuat pengkajian perawat lebih komprehensif dan spesifik berorientasi pada masalah dan diagnosis pasien.

Situasi aktual atau nyata yang mendukung dilakukannya rawat inap pada pasien umumnya didapatkan dari keluhan utama pasien secara spesifik yang mengakibatkan pasien mencari layanan perawatan dan biasanya berhubungan dengan penyakitnya. Namun ada persepsi bahwa keluhan utama adalah keluhan yang pasien sampaikan secara subyektif pada saat interaksi pertama kali, padahal tidak semua yang dikeluhkan pasien saat pertama kali berinteraksi dengan perawat merupakan alasan pasien datang ke layanan kesehatan tetapi apa yang pasien rasakan pada saat ditanya oleh perawat.

Intervensi keperawatan dibuat untuk mencapai tujuan dan kriteria hasil yang diharapkan guna mengatasi etiologi dan menyelesaikan masalah keperawatan. Intervensi dibuat secara spesifik dan operasional yang terdiri dari aktivitas apa yang akan dilakukan, bagaimana, seberapa sering, dan lebih baik lagi jika teridentifikasi siapa yang melakukan. Prinsip tersebut perlu dilakukan supaya tiap perawat yang melihat perencanaan keperawatan mudah untuk melakukannya atau mengaplikasikan rencana tersebut. Setelah tindakan telah dilakukan, tiap 
intervensi dievaluasi berdasarkan respon pasien terhadap tiap tindakan yang telah diimplementasikan dan mengacu atau berorientasi pada kriteria hasil yang telah ditetapkan (Abdelkader, Othman, 2017).

Prinsip lain yang juga menjadi dasar proses intervensi-implementasi adalah "lakukan apa yang ditulis" (intervensi-implementasi) dan "tulis apa yang dilakukan" (implementasidokumentasi). Kedua prinsip tersebut merupakan dasar pendokumentasian/pencatatan dan pelaporan asuhan keperawatan. Prinsip tersebut akan mempertahankan aspek legal dan etik keperawatan serta dapat melindungi perawat dari segi atau aspek hukum dan etik. Pada bahasan diagnosis keperawatan telah dipaparkan satu contoh tentang masalah keperawatan yang didasari oleh tanda dan gejala yakni kekuatan otot pada pasien stroke. Untuk intervensi, perlu dilakukan pemilihan tindakan apa yang dilakukan untuk mengatasi masalah tersebut, salah satu intervensi yang dapat dilakukan untuk dipilih dalam mengatasi kekuatan otot adalah dengan latihan menggenggam (Daeli et al., 2018). Latihan menggenggam merupakan salah satu bagian dari Range of Motion, yang juga dapat digunakan untuk melatih sendi pasien yang mengalami gangguan sehingga dapat berfungsi dengan maksimal sesuai dengan fungsi dasarnya (Pranata et al., 2019). Aplikasi dari contoh intervensi yang telah dipaparkan merupakan gambaran penegakkan rencana keperawatan yang akan diimplementasikan pada asuhan keperawatan pasien.

Perawat sebagai tenaga kesehatan yang profesional mempunyai kesempatan yang paling besar untuk memberikan pelayanan kesehatan khususnya pelayanan atau asuhan keperawatan yang komprehensif dengan membantu pasien memenuhi kebutuhan dasar yang holistik. Perawat memandang pasien sebagai makhluk biopsikososio-kultural dan spiritual yang berespon secara holistik dan unik terhadap perubahan kesehatan atau pada keadaan krisis. Asuhan keperawatan yang diberikan oleh perawat tidak bisa terlepas dari aspek spiritual yang merupakan bagian integral dari interaksiperawat dengan pasien. Perawat berupaya membantu memenuhi kebutuhan spiritual pasien sebagai bagian dari kebutuhan menyeluruh pasien, antara lain dengan mengimplementaikan kebutuhan spiritual pasien tersebut, walaupun perawat dan pasien tidak mempunyai keyakinan spiritual atau keagamaan yang sama. Hal ini juga didukung berdasarkan penelitian Samsualam pada Tahun 2016 penerapan asuhan keperawatan dalam pemenuhan kebutuhan spiritual klien dapat dilakukan antara lain dengan, pengkajian pemahaman klien tentang spiritual, pengkajian tentang kebiasaan berdo'a pada klien, memberikan kesempatan dan 
membantu klien untuk dapat menjalankan kewajiban agamanya, membantu klien melakukan rutinitas peribadatannya, mendengarkan keluhan atau perasaan klien, berdiskusi dengan klien tentang spiritual. Sedangkan pada kondisi klien yang tidak sadar maka prioritas pemenuhan kebutuhan spiritual pada; membisikkan do'a kepada klien, mendoakan klien, menyiapkan kondisi yang tenang untuk klien.

\section{PENUTUP}

\section{KESIMPULAN}

Mengimplementasikan intervensi keperawatan Implementasi intervensi keperawatan yang berhasil membutuhkan keterampilan kognitif, interpersonal dan psikomotor

1) Keterampilan kognitif keterampilan kognitif meliputi aplikasi keterampilan pemikiran kritis pada proses keperawatan. Untuk melaksanaakn intervensi dibutuhkan pertimbangan yang baik dan keputusan klinis yang jelas, ini berarti intervensi keperawatan tidak bersifat otomatis, perawat harus berfikir dan mengantisipasi secara kontinou, sehingga perawat dapat menyesuaikan perawatan klien dengan tepat.

2) Keterampilan Interpersonal keterampilan ini dibutuhkan untuk terwujudnya tindakan keperawatan yang efektif. Perawat membangun keperacayaan, menunjukkan perhatian dan berkomunikasi dengan jelas

3) Keterampilan Psikomotor keterampilan psikomotor membutuhkan integritas antara kativitas kognitif dan motorik. Sebagai contoh, saat melakukan penyuntikan, perawat harus memahami anatomi dan farmakologi (kognitif)., serta menggunakan koordinasi dan presisi untuk melakukan penyuntikan dengan tepat (motorik). Keterampilan ini sangat penting untuk membangun kepercayaan klien. 


\section{DAFTAR PUSTAKA}

Astar, Fatmawati., Tamsah, Hasmin., Kadir, Ikhasan. 2017. PENGARUH PELAYANAN ASUHAN

KEPERAWATAN TERHADAP KEPUASAN PASIEN DI PUSKESMAS TAKALALA KABUPATEN

SOPPENG. MIRAI : JOURNAL OF MANAGEMENT, 1(2).

Butar-Butar, J., \& Simamora, R. H. (2016). Hubungan Mutu Pelayanan Keperawatan dengan Tingkat Kepuasan Pasien Rawat Inap di RSUD Pandan Kabupaten Tapanuli Tengah. Jurnal Ners Indonesia, 6(1), 50-63.

Dewi, Inggriane, Puspita., Nurrohmah., Fadlurrahman, Fikri, Rizki. 2020. Analisis Pengetahuan Perawat dalam Menentukan Diagnosis Asuhan Keperawatan Spiritual Islami di Rumah Sakit Syariah. Jurnal Ilmiah Keperawatan Indonesia, 4(1).

Koemiawani, Dheni., Daeli, Novita, Elisabeth., Srimiyati. 2020. APLIKASI STANDAR PROSES KEPERAWATAN: DIAGNOSIS, OUTCOME, DAN INTERVENSI PADA ASUHAN KEPERAWATAN. Jurnal Keperawatan Silampari, 3(2).

Samsualam., Hidayat, Rahmat., Lestari, Karyanti. 2018. Studi Eksplorasi Religiusitas dan Implementasi Asuhan Keperawatan Spiritual Muslim PSIK FKM UMI 2018. Window of Health : Jurnal Kesehatan, 1(4).

S, Wulandari, Purti., Krianto, Tri., Priwahyuni, Yuyun. 2016. FAKTOR-FAKTOR YANG BERHUBUNGAN DENGAN PENDOKUMENTASIAN ASUHAN KEPERAWATAN DI RUMAH SAKIT JIWA. NERS JURNAL KEPERAWATAN, 12(2).

Simamora, R. H. (2005). Hubungan Persepsi Perawat Pelaksana Terhadap Penerapan Fungsi

Pengorganisasian Yang Dilakukan Oleh Kepala Ruangan Dengan Kinerjanya Diruang Rawat Inap RSUD Koja Jakarta Utara (Doctoral dissertation, Tesis FIK UI, Tidak dipublikasikan).

Sugiyati, Sri. 2015. HUBUNGAN PENGETAHUAN PERAWAT DALAM DOKUMENTASI KEPERAWATAN DENGAN PELAKSANAANNYA DI RAWAT INAP RSI KENDAL. Jurnal Keperawatan, 8(2). 